\title{
The global atmospheric budget of ethanol revisited
}

\author{
W. V. Kirstine ${ }^{1,2}$ and I. E. Galbally ${ }^{2}$ \\ ${ }^{1}$ School of Applied Sciences \& Engineering, Monash University, Churchill, Victoria 3840, Australia \\ ${ }^{2}$ Centre for Australian Weather and Climate Research, CSIRO Marine \& Atmospheric Research, \\ Aspendale, Victoria 3195, Australia
}

Correspondence to: W. V. Kirstine (wayne.kirstine@csiro.au)

Received: 11 August 2011 - Published in Atmos. Chem. Phys. Discuss.: 16 September 2011

Revised: 6 December 2011 - Accepted: 22 December 2011 - Published: 11 January 2012

\begin{abstract}
Ethanol is an important biogenic volatile organic compound, which is increasingly used as a fuel for motor vehicles; therefore, an improved understanding of its atmospheric cycle is important. In this paper we use three sets of observational data, measured emissions of ethanol from living plants, measured concentrations of ethanol in the atmosphere and measured hydroxyl concentrations in the atmosphere (by methyl chloroform titration), to make two independent estimates related to the rate of cycling of ethanol through the atmosphere. In the first estimate, simple calculations give the emission rate of ethanol from living plants as 26 (range, 10-38) $\mathrm{Tg} \mathrm{yr}^{-1}$. This contributes significantly to the total global ethanol source of 42 (range, 25-56) $\mathrm{Tg} \mathrm{yr}^{-1}$. In the second estimate, the total losses of ethanol from the global atmosphere are 70 (range, 50-90) $\mathrm{Tg} \mathrm{yr}^{-1}$, with about three-quarters of the ethanol removed by reaction with hydroxyl radicals in the gaseous and aqueous phases of the atmosphere, and the remainder lost through wet and dry deposition to land. These values of both the source of ethanol from living plants and the removal of atmospheric ethanol via oxidation by hydroxyl radicals (derived entirely from observations) are significantly larger than those in recent literature. We suggest that a revision of the estimate of global ethanol emissions from plants to the atmosphere to a value comparable with this analysis is warranted.
\end{abstract}

\section{Introduction}

Ethanol is a widely used organic compound, best known for its role in alcoholic beverages and as a fuel additive or extender. It is also recognised as a minor biogenic volatile organic compound (BVOC) in the atmosphere. Since the first atmo- spheric measurements of ethanol made by Snider and Dawson (1985) in the United States and Jonsson et al. (1985) in Sweden, there have been limited observations of ethanol because of its low atmospheric mixing ratio and the difficulties associated with its analysis. There are also large regional differences in the atmospheric mixing ratios of ethanol due to the wide variation in biogenic and anthropogenic contributions (Naik et al., 2010).

The paucity of atmospheric measurements of ethanol mixing ratios and emissions makes it difficult to precisely quantify its sources and sinks. To date, three summaries of the global atmospheric budget of ethanol have been published (Singh et al., 2004; Millet et al., 2010; Naik et al., 2010), although only Naik et al. (2010) present a detailed analysis of the atmospheric sources and sinks of ethanol. These studies agree that the largest atmospheric source of ethanol is from emissions by living plants, with smaller contributions from plant litter, biomass burning, atmospheric chemistry and anthropogenic production. The major removal process for ethanol from the atmosphere is oxidation by hydroxyl radicals $(\cdot \mathrm{OH})$. Wet deposition and dry deposition constitute smaller sinks. Naik et al. (2010) found that the ethanol mixing ratios predicted by their global chemical transport model for the continental boundary layer (CBL) were significantly smaller than measured values - suggesting a large missing source of ethanol in the CBL. Naik et al. (2010) identified that an in situ source of ethanol of $10 \mathrm{pptv}^{\mathrm{day}}{ }^{-1}$ (29.3 $\mathrm{Tg} \mathrm{yr}^{-1}$ ) could bring the model and observations into alignment. Naik et al. (2010) explored whether this rate of atmospheric chemical production of ethanol was possible, and concluded not. Thus, a major non-atmospheric source of ethanol is missing. 


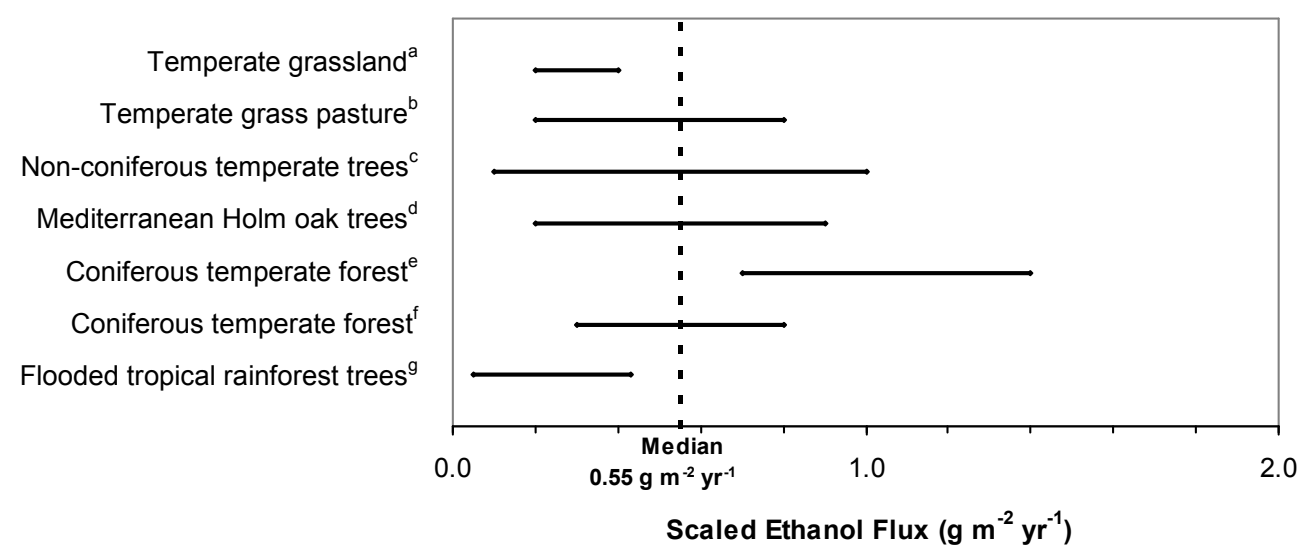

Fig. 1. Scaled annual estimates of ethanol emissions from plants based on the ethanol emission fluxes available in the literature. References are ${ }^{\mathrm{a}}$ Fukui and Doskey (1998), ${ }^{\mathrm{b}}$ Kirstine et al. (1998), ${ }^{\mathrm{c}}$ Helmig et al. (1999), ${ }^{\mathrm{d}}$ Holzinger et al. (2000), ${ }^{\mathrm{e}}$ Schade and Goldstein (2001), ${ }^{\mathrm{f}}$ Grabmer et al. (2006), ${ }^{\mathrm{g}}$ Rottenberger et al. (2008).

The arguments presented here, consistent with the suggestion of Naik et al. (2010), are that previous global atmospheric budgets of ethanol underestimate the total ethanol sources and sinks, and that ethanol production from living plants and/or anthropogenic sources may be considerably larger than estimated in recent budgets. For this analysis, a compilation has been made of all of the plant emission measurements and the atmospheric ethanol measurements found in the literature. In this study, we more than double the database of ethanol emission fluxes from vegetation used by Naik et al. (2010). The inclusion of these extra studies allows the consideration of the effects of root flooding and plant stress on the emission of ethanol from plants, not included in the Naik et al. (2010) paper.

\section{Ethanol emissions from plants to the atmosphere and the sources of atmospheric ethanol}

When plants experience conditions where sufficient oxygen is unavailable for normal (aerobic) respiration, most plants are able to maintain energy production by fermentation (Kimmerer and MacDonald, 1987; Kreuzwieser et al., 2004). Ethanol is a by-product of this fermentation process. Much of this ethanol is metabolised within the plant, but a portion is emitted from the plant's leaves or stems to the atmosphere (MacDonald and Kimmerer, 1993). Ethanol emissions by plants are significantly enhanced under anaerobic or stress conditions, such as frost, drought or flooding (Fukui and Doskey, 1998; Rottenberger et al., 2008). An estimate of the magnitude of the global ethanol source from living plants is reliant on measurements of ethanol fluxes from plants. The global emission of ethanol from plants is the sum over all biomes of the products of the average emission of ethanol from each biome $\left(E_{i}\right)$ times the area of that biome $\left(A_{i}\right)$.
$E_{T}=\sum_{i} E_{i} \cdot A_{i}$

The uncertainty in the global emission of ethanol is the result of the combined uncertainties in each of the biome estimates.

Seven studies of ethanol emissions from plant species or ecosystems occur in the literature (Fig. 1). We initially discuss each of these studies, which vary in design and duration, and extrapolate an annual average ethanol emission and/or range of emissions for each study. In extrapolating to annual average emissions we have assumed zero night-time emissions and reduced emissions in winter depending on the biome.

In the following discussion, we initially retain the original units of emission used by the authors, but when we combine the data, such as in Fig. 1, we reduce the data to consistent SI units. Throughout this study, where a standard deviation is given, it is preceded by \pm , and where a range is provided it represents notionally two standard deviations each way from the mean. In determining global sources and sinks of ethanol, the uncertainties in the individual components are combined using root-sum-of-squares (RSS) analysis.

Fukui and Doskey (1998) measured ethanol emission fluxes from a grassland ecosystem in the midwestern United States over most of the growing season. The average of all the ethanol fluxes measured during the study period was $206 \mu \mathrm{g} \mathrm{m}^{-2} \mathrm{~h}^{-1}$, with the largest fluxes occurring after a severe frost event or after the plots were waterlogged following heavy rain. Using the data of Fukui and Doskey (1998), we estimate that for a simulated growing season in a typical temperate region with 1000-2000 daylight hours, two waterlogged periods and one severe frost event, as observed by Fukui and Doskey (1998), the average ethanol flux would be 0.2-0.4 g (ethanol) $\mathrm{m}^{-2} \mathrm{yr}^{-1}$ (Fig. 1). Kirstine et al. (1998) investigated BVOC emissions from a grass pasture in southeastern Australia and estimated a total BVOC flux of $1.9 \mathrm{~g}$ (C) $\mathrm{m}^{-2} \mathrm{yr}^{-1}$ over the growing season. During a hot, dry 
period in the summer, $6-21 \%$ of the BVOC flux consisted of ethanol. This is equivalent to an ethanol flux of $0.2-0.8 \mathrm{~g}$ (ethanol) $\mathrm{m}^{-2} \mathrm{yr}^{-1}$ (Fig. 1).

Two studies of ethanol emissions from coniferous plant ecosystems have been conducted involving a pine (Pinus ponderosa) plantation in California (Schade and Goldstein, 2001), and a spruce (Picea abies) forest in Germany (Grabmer et al., 2006). These two studies measured ethanol emissions over 90 and 60 days, respectively, during the summer and recorded typical diurnal patterns with a burst of ethanol in the morning when the leaf stomata opened, a peak around midday and a gradual decrease toward zero in the late afternoon as the stomata closed.

Helmig et al. (1999) and Holzinger et al. (2000) measured ethanol emissions from potted specimens of non-coniferous trees. Since these were short-term studies conducted under optimum growing conditions, typically observed diurnal and seasonal variations from Schade and Goldstein (2001) and Grabmer et al. (2006) were used to calculate the annual integrated ethanol emissions shown in Fig. 1. Representative foliage mass densities were taken from Guenther et al. (1994).

In a study of BVOC emissions from evergreen tree specimens representative of the floodplain rainforest of the Central Amazon, Rottenberger et al. (2008) determined daily integrated ethanol fluxes for potted plants of four species during simulated flood conditions. Temperature, PAR and humidity were controlled to mimic the natural environment. Daily integrated emission rates over the 1-2 weeks of the flooding simulations varied from about $0-160 \mu \mathrm{mol} \mathrm{m}^{-2} \mathrm{~d}^{-1}$, with the lower values occurring prior to flooding and the higher values occurring 3-6 days after the plant pots were flooded. Large variations in emissions occurred among the four species. If these flooded conditions are representative of 210 days per year, which the authors considered to be typical of forests in this region, the annual averaged ethanol emission fluxes of the four species would lie within a range of approximately $0.05-0.43 \mathrm{~g}$ (ethanol) $\mathrm{m}^{-2} \mathrm{yr}^{-1}$, with the value depending on the frequency of flood events.

Given the ranges associated with the extrapolated annual fluxes from the measured ethanol emissions, there is little difference in the ethanol emission fluxes observed in all seven studies in Fig. 1. We estimate that the median of the ranges of the scaled annual fluxes of all the available ethanol emissions from vegetation in Fig. 1 is equal to about $0.55 \mathrm{~g} \mathrm{~m}^{-2} \mathrm{yr}^{-1}$.

There are two ways in which this data set could be extrapolated to give a global ethanol emission estimate using Eq. (1). In the first approach, the median of the observed emissions could be multiplied by the global area of vegetation to give one emission estimate. In the second approach, it could be assumed that the individual emission studies provide information about coherent species or regional differences in the ethanol emissions. In this case, each of the emissions could be multiplied by the area it is thought to represent and the sum of these products would give a second emission estimate. Because there is probably no significant difference (taking into account the limited number of observations in each study) in the annual average emissions derived from measurements on the different ecosystems shown in Fig. 1, this second approach is not pursued.

We assume that the areas of grasslands, tundra and forests above latitudes of $60^{\circ}$ have zero ethanol emissions as the temperatures at these latitudes are likely to be too low for significant emissions of ethanol. Also, zero emissions are assigned to non-flooded rainforest, cultivated land, desert and semi-arid shrubland due to the lack of observations of ethanol fluxes for these areas.

Using the first approach, the average emission is multiplied by the total global area (within the boundaries of $60^{\circ} \mathrm{N}$ to $60^{\circ} \mathrm{S}$ ) of grasslands, coniferous and non-coniferous forests, and seasonally-flooded tropical rainforests (Esser, 1992; Potter, 1999) to estimate a global ethanol emission from vegetation of $26 \mathrm{Tg} \mathrm{yr}^{-1}$. Because of the small data set, statistical analysis is an insufficient basis for quantifying the uncertainty in the data, and judgement must be used (Cullen and Frey, 1999). We define the range of the global average emission in terms of the median of the lower values of the range and the median of the higher values of the range in Fig. 1. Thus, the range for the global emission estimate is $10-38 \mathrm{Tg} \mathrm{yr}^{-1}$.

In our estimation, the most serious neglect in this calculation is the omission of potential ethanol emissions from wetlands (excluding flooded forests) and rice paddies. There is evidence of ethanol in the soils of these systems (Metje and Frenzel, 2005; Chawanakul et al., 2009), but there are no measurements of ethanol emissions from wetlands or rice paddies to the atmosphere. Such emissions would increase the estimate of the global plant ethanol emissions to the atmosphere.

This study suggests that living plants are a significant source of atmospheric ethanol, with an estimate of 26 (range, 10-38) $\mathrm{Tg} \mathrm{gr}^{-1}$. The previous studies have estimated 6 (range, 4-8) $\mathrm{Tg} \mathrm{yr}^{-1}$ (Singh et al., 2004), $17 \mathrm{Tg} \mathrm{yr}^{-1}$ (Millet et al., 2010), and 9.2 $\mathrm{Tg} \mathrm{yr}^{-1}$ (Naik et al., 2010) for the global plant production of ethanol. In this study, the global plant production of ethanol estimated from the observed emissions is, on average, larger than that of previous studies (although the range of the emissions includes the largest estimate of the above studies, Millet et al., 2010).

\section{Other sources of atmospheric ethanol}

To understand the global cycle of ethanol, other sources as well as plants must be quantified. Estimates are available in the literature for ethanol emissions from plant decay, biomass burning, atmospheric production and anthropogenic sources (Singh et al., 2004; Millet et al., 2010; Naik et al., 2010). Following a comprehensive review, we add two additional sources not previously quantified: the ethanol emitted from 
Table 1. Global atmospheric sources of ethanol in $\mathrm{Tg}$ (ethanol) $\mathrm{yr}^{-1}$. Numbers in parentheses are estimated ranges of the sources and sinks.

\begin{tabular}{|c|c|c|c|c|c|}
\hline $\begin{array}{l}\text { Sources } \\
\left(\operatorname{Tg~yr}^{-1}\right)\end{array}$ & $\begin{array}{l}\text { Singh et al. } \\
(2004)\end{array}$ & $\begin{array}{l}\text { Millet et al. } \\
\text { (2010) }\end{array}$ & $\begin{array}{l}\text { Naik et al. } \\
\text { (2010) }\end{array}$ & $\begin{array}{l}\text { Naik et al. } \\
\text { (2010) }\end{array}$ & $\begin{array}{l}\text { This study } \\
\text { (Approach 1) }\end{array}$ \\
\hline & & & BASE & SYNEOH & \\
\hline Living plants & $6(4-8)$ & 17 & 9.2 & 9.2 & $26(10-38)$ \\
\hline Plant decay & small & 6 & & & $3(1-6)^{\mathrm{a}}$ \\
\hline Herbivory & & & & & $1.6(0.5-3)^{b}$ \\
\hline Biomass burning & $2(1-3)$ & 0.07 & 0.47 & 0.47 & $0.8(0.1-2)^{\mathrm{a}}$ \\
\hline Soil and water & $0(0-1)$ & & & & ? \\
\hline Anthropogenic & $2(1-2)$ & 2 & 5.0 & 5.0 & $6(2-10)^{\mathrm{b}}$ \\
\hline Atmospheric & $2(1-3)$ & 0.3 & 0.06 & 29.4 & $0.5(0.05-1.5)^{\mathrm{a}}$ \\
\hline Ocean & & & & & $4(3-5)^{\mathrm{c}}$ \\
\hline Total sources & $12(7-17)$ & 25 & 14.7 & 44.1 & $42(25-56)$ \\
\hline
\end{tabular}

${ }^{\mathrm{a}}$ average of the values from Singh et al. (2004), Millet et al. (2010) and Naik et al. (2010), ${ }^{\mathrm{b}}$ Kirstine and Galbally (2011), ${ }^{\mathrm{c}}$ Beale et al. (2010)

animal manure (Kirstine and Galbally, 2011) and ethanol emitted from the ocean (Beale et al., 2010).

Ethanol is formed by the microbial fermentation of residual carbohydrates in the manure of cows (Filipy et al., 2006; Sun et al., 2008). Using observations of such emissions from the available literature (Filipy et al., 2006; Shaw et al., 2007; Sun et al., 2008; Ngwabie et al., 2008; Chung et al., 2010), we estimate that, on a global scale, dairy cows and confined beef cattle and their manure produce about 1.6 (range, $0.5-$ 3) $\mathrm{Tg}_{\mathrm{yr}}^{-1}$ of ethanol.

In a recent study by Beale et al. (2010) in the Atlantic Ocean, the ethanol concentrations of surface ocean water were found to be in the range of 2 to $33 \mathrm{nM}$, with maximum concentrations occurring in pre-dawn samples and the smallest concentrations in the afternoon. Regional variations in ethanol concentration were noted, suggesting significant variation in ethanol production in the ocean surface layer. From these measurements, Beale et al. (2010) estimated a global annual ethanol source from the ocean of approximately 4 (range, $3-5$ ) $\mathrm{Tg} \mathrm{yr}^{-1}$.

The estimates of the various sources of atmospheric ethanol are gathered in Table 1. We estimate the total global ethanol source to be 42 (range, $25-56) \mathrm{Tg} \mathrm{yr}^{-1}$. This provides our first estimate of the rate of ethanol cycling through the atmosphere. The large uncertainty associated with this estimate is a consequence of the existence of only seven studies of ethanol emission fluxes from plants, some of short duration.

Our estimate of the global ethanol source, based on measured ethanol emission fluxes, is equal to the global ethanol turnover of $44.0 \mathrm{Tg} \mathrm{yr}^{-1}$ derived by Naik et al. (2010) in their SYNEOH model, where they introduced an additional $29.3 \mathrm{Tg} \mathrm{yr}^{-1}$ source into the atmosphere to bring the model and observations into alignment. The distinction is that, in our study, the additional production of ethanol was a con- sequence of large emissions from living plants, rather than from secondary atmospheric precursors.

The global production of ethanol from plants is hard to determine with high precision because it is strongly influenced by anaerobic or other stress conditions that are difficult to simulate without sufficient long-term studies of fluxes from representative biomes. Thus, successful global modelling is likely to require constraints from the ethanol sinks derived from measurements of ethanol mixing ratios in the atmosphere.

\section{The magnitude of the ethanol sink in the atmosphere}

We estimate the global rate of ethanol removal from the atmosphere based on observed ethanol concentrations in the atmosphere. Assuming steady-state conditions for ethanol in the atmosphere over the course of a year, the total global annual sink for ethanol should be equal to the total global annual source. Therefore, a determination of the magnitude of global ethanol removal processes may be used as a check on the magnitude of the global ethanol sources.

\subsection{Ethanol concentrations in the atmosphere}

Ethanol is a minor BVOC in the global troposphere. The available body of ethanol concentration measurements in the atmosphere are analysed here. We note that various observations of atmospheric ethanol are presented in Naik et al. (2010) and referenced to earlier papers (Warneke et al., 2005; Singh et al., 2006, 2009; Murphy et al., 2007), but the ethanol data are not presented in these earlier papers. We assume that ethanol measurements were made by the same authors alongside the other measurements reported in these papers, and these ethanol measurements are presented for the first time in Naik et al. (2010). 
Table 2a. Mixing ratios of ethanol in the continental boundary layer.

\begin{tabular}{lllll}
\hline Region & Latitude & $\begin{array}{l}\text { Duration } \\
\text { of Study }\end{array}$ & $\begin{array}{l}\text { Mixing Ratios } \\
\left(\mathrm{nmol} \mathrm{mol}^{-1}\right)\end{array}$ & References \\
\hline Coastal & & & & \\
\hline Trinidad Head, California & $41^{\circ} \mathrm{N}$ & Apr-May & $0.11^{\mathrm{b}}$ & Millet et al. (2004) \\
Chebogue Point, Canada & $44^{\circ} \mathrm{N}$ & Jul-Aug & $0.11^{\mathrm{b}}$ & Millet et al. (2006) \\
Galveston Bay, Texas, USA & $29-30^{\circ} \mathrm{N}$ & Aug-Sep & $0.87^{\mathrm{a}}$ & Gilman et al. (2009) \\
Granite Bay, California & $39^{\circ} \mathrm{N}$ & Jul-Sep & $1.90^{\mathrm{c}}$ & Naik et al. (2010) \\
\hline Rural/remote & & & & \\
\hline Rural sites, near Tucson, Arizona & $32^{\circ} \mathrm{N}$ & Aug-Sep & $0.40^{\mathrm{a}}$ & Snider and Dawson (1985) \\
Recreational reserve, Stockholm & $59^{\circ} \mathrm{N}$ & May-Jun & $2.6^{\mathrm{a}}$ & Jonsson et al. (1985) \\
Rural site, Alabama & $32^{\circ} \mathrm{N}$ & & $2.3^{\mathrm{a}}$ & Fehsenfeld et al. (1992) \\
Forest plantation, Alabama & $32^{\circ} \mathrm{N}$ & Jun-Jul & $1.2^{\mathrm{a}}$ & Goldan et al. (1995a) \\
Wank Mountains, Germany & $48^{\circ} \mathrm{N}$ & Jul-Aug & $0.24^{\mathrm{a}}$ & Leibrock and Slemr (1997) \\
Rural site, Tennessee & $36^{\circ} \mathrm{N}$ & Jun & $0.38^{\mathrm{a}}$ & Riemer et al. (1998) \\
Mesa near Boulder, Colorado & $40^{\circ} \mathrm{N}$ & Feb & $2.6^{\mathrm{a}}$ & Goldan et al. (1995b) \\
Sierra Nevada pine forest & $39^{\circ} \mathrm{N}$ & Jul-Sep & $2.5^{\mathrm{a}}$ & Schade and Goldstein (2001) \\
INTEX-NA Study, USA/Canada & $27-53^{\circ} \mathrm{N}$ & Jul-Aug & $0.40^{\mathrm{c}}$ & Naik et al. (2010) \\
Remote spruce forest, Germany & $50^{\circ} \mathrm{N}$ & Jul-Aug & $0.7^{\mathrm{a}}$ & Grabmer et al. (2006) \\
INTEX-B Study, USA/Mexico & $15-60^{\circ} \mathrm{N}$ & Mar & $0.30^{\mathrm{c}}$ & Naik et al. (2010) \\
High alpine site, Switzerland & $47^{\circ} \mathrm{N}$ & Summer & $0.12^{\mathrm{a}}$ & Legreid et al. (2008) \\
High alpine site, Switzerland & $47^{\circ} \mathrm{N}$ & Winter & $0.31^{\mathrm{a}}$ & Legreid et al. (2008) \\
\hline & & & &
\end{tabular}

${ }^{\mathrm{a}}$ mean of measurements, ${ }^{\mathrm{b}}$ median of measurements, ${ }^{\mathrm{c}}$ mean of measurements from surface to $2 \mathrm{~km},{ }^{\mathrm{d}}$ supplied by other authors

Table 2b. Mixing ratios of ethanol in the urban continental boundary layer.

\begin{tabular}{lllll}
\hline Region & Latitude & $\begin{array}{l}\text { Duration } \\
\text { of Study }\end{array}$ & $\begin{array}{l}\text { Mixing Ratios } \\
\left(\mathrm{nmol} \mathrm{mol}^{-1}\right)\end{array}$ & References \\
\hline Urban & & & & \\
\hline Tucson, Arizona, USA & $32^{\circ} \mathrm{N}$ & Feb-Sep & $3.3^{\mathrm{a}}$ & Snider and Dawson (1985) \\
Osaka, Japan & $35^{\circ} \mathrm{N}$ & May-Dec & $8.2^{\mathrm{a}}$ & Nguyen et al. (2001) \\
Pittsburg, USA & $40^{\circ} \mathrm{N}$ & Jan-Feb & $0.99^{\mathrm{b}}$ & Millet et al. (2005) \\
Pittsburg, USA & $40^{\circ} \mathrm{N}$ & Jul-Aug & $1.7^{\mathrm{b}}$ & Millet et al. (2005) \\
Wuppertal, Germany & $51^{\circ} \mathrm{N}$ & Aug-Oct & $0.78^{\mathrm{a}}$ & Niedajadlo et al. (2007) \\
Zürich, Switzerland & $47^{\circ} \mathrm{N}$ & Summer & $3.9^{\mathrm{a}}$ & Legreid et al. (2007) \\
Zürich, Switzerland & $47^{\circ} \mathrm{N}$ & Winter & $7.5^{\mathrm{a}}$ & Legreid et al. (2007) \\
Brazil (various locations) & $13-30^{\circ} \mathrm{S}$ & 1 min-4h & $162^{\mathrm{a}}$ & Anderson (2009) \\
\hline
\end{tabular}

${ }^{a}$ mean of measurements, ${ }^{b}$ median of measurements, ${ }^{c}$ mean of measurements from surface to $2 \mathrm{~km},{ }^{d}$ supplied by other authors

In the non-urban CBL of the Northern Hemisphere (NH), the mixing ratio of ethanol has been measured in the range from 0.1 to $2.6 \mathrm{nmol} \mathrm{mol}^{-1}$, with the lower values being in remote sites (Table 2). The larger mixing ratios of ethanol in rural areas, when compared with those of the remote or coastal troposphere, indicate the presence of a strong source of ethanol in rural regions of the CBL, probably mostly biogenic. Using the arithmetic mean of the non-urban observations in Table 2, an ethanol mixing ratio of $1 \mathrm{nmol} \mathrm{mol}^{-1}$ (range, $0.6-1.8 \mathrm{nmol} \mathrm{mol}^{-1}$ ) is estimated to be representa- tive of the relatively unpolluted CBL. On the basis of similar ratios of vegetation to total land area, we assume that the ethanol mixing ratio in the CBL of the Southern Hemisphere $(\mathrm{SH})$ is the same as that in the $\mathrm{NH}$, namely $1 \mathrm{nmol} \mathrm{mol}^{-1}$. The ethanol mixing ratios of urban areas (Table 2) are not included in this assessment because the global urban area accounts for less than $0.7 \%$ of the total global land area (Potere et al., 2009).

Ethanol mixing ratios in the free troposphere (FT), including the snow-covered Arctic, indicate a range of $<0.05$ 
Table 3. Mean mixing ratios of ethanol in the free troposphere and marine boundary layer.

\begin{tabular}{|c|c|c|c|}
\hline Region & $\begin{array}{l}\text { Duration } \\
\text { of Study }\end{array}$ & $\begin{array}{l}\text { Mixing Ratios } \\
\left(\mathrm{nmol} \mathrm{mol}^{-1}\right)\end{array}$ & References \\
\hline \multicolumn{4}{|l|}{ Free Troposphere } \\
\hline $\begin{array}{l}\text { Pacific Ocean } \\
\left(10^{\circ} \mathrm{S}-36^{\circ} \mathrm{N}\right)\end{array}$ & Feb-Mar & $\begin{array}{l}0-0.2 \\
\text { median }=0.05\end{array}$ & Singh et al. (1995) \\
\hline $\begin{array}{l}\text { Atlantic Ocean } \\
\left(40-65^{\circ} \mathrm{N}\right)\end{array}$ & Oct-Nov & $<0.050$ & Singh et al. (2000) \\
\hline $\begin{array}{l}\text { Pacific Ocean } \\
\left(30^{\circ} \mathrm{S}-30^{\circ} \mathrm{N}\right)\end{array}$ & Mar-Apr & $<0.050$ & Singh et al. (2001) \\
\hline $\begin{array}{l}\text { Alert, Nunavut, } \\
\text { Canada }\left(82.5^{\circ} \mathrm{N}\right)\end{array}$ & $\begin{array}{l}\text { Feb-Mar } \\
\text { (dark) }\end{array}$ & $0.099 \pm 0.091$ & Boudries et al. (2002) \\
\hline $\begin{array}{l}\text { Alert, Nunavut, } \\
\text { Canada }\left(82.5^{\circ} \mathrm{N}\right)\end{array}$ & $\begin{array}{l}\text { Apr-May } \\
\text { (daylight) }\end{array}$ & $0.036 \pm 0.031$ & Boudries et al. (2002) \\
\hline $\begin{array}{l}\text { Pacific Ocean } \\
\left(14-40^{\circ} \mathrm{N}\right)\end{array}$ & Feb-Apr & $0.072^{\mathrm{a}}$ & Singh et al. (2004) \\
\hline \multicolumn{4}{|c|}{ Marine Boundary Layer } \\
\hline $\begin{array}{l}\text { Pacific Ocean } \\
\left(14-40^{\circ} \mathrm{N}\right)\end{array}$ & Feb-Apr & $0.17 \pm 0.25^{\mathrm{b}}$ & Singh et al. (2004) \\
\hline $\begin{array}{l}\text { North Atlantic } \\
\left(41-44^{\circ} \mathrm{N}\right)\end{array}$ & Jul-Aug & $0.23 \pm 0.20$ & de Gouw et al. (2005) \\
\hline $\begin{array}{l}\text { Gulf of Mexico, } \\
\text { USA }\left(25-28^{\circ} \mathrm{N}\right)\end{array}$ & Jul-Aug & $0.036^{\mathrm{a}}$ & Gilman et al. (2009) \\
\hline $\begin{array}{l}\text { North Atlantic } \\
\left(42-44^{\circ} \mathrm{N}\right)\end{array}$ & Jul-Aug & $0.32 \pm 0.43$ & Naik et al. $(2010)^{\mathrm{c}}$ \\
\hline
\end{tabular}

${ }^{\mathrm{a}}$ mean of measurements, ${ }^{\mathrm{b}}$ mean of measurements from surface to $2 \mathrm{~km},{ }^{\mathrm{c}}$ supplied by other authors

to $0.1 \mathrm{nmol} \mathrm{mol}^{-1}$ (Singh et al., 1995, 2004; Boudries et al., 2002) (Table 3). In this study, we use the median of the measurements provided by Singh et al. (1995), namely $0.05 \mathrm{nmol} \mathrm{mol}^{-1}$, as an estimate of the average mixing ratio of ethanol in the FT. There is no significant difference between the median of this data set and that of Singh et al. (2004). It appears from the available observations that the mixing ratio of ethanol in the FT is about twenty times less than that in the relatively unpolluted CBL.

Mean ethanol mixing ratios in the marine boundary layer (MBL) vary from 0.036 to $0.32 \mathrm{nmol} \mathrm{mol}^{-1}$ (Singh et al., 2004; de Gouw et al., 2005; Gilman et al., 2009; Naik et al., 2010) (Table 3). An analysis of the results from aircraft campaigns by Naik et al. (2010) found that the ethanol mixing ratio decreased by a factor of about four from the surface to an altitude of $5 \mathrm{~km}$ for measurements taken during the INTEX-NA and INTEX-B campaigns, but other studies identified smaller vertical gradients, or even reversed vertical gradients, possibly due to strong regional convective influences. Using the vertical atmospheric profiles of ethanol sug- gested by the measurements of Singh et al. (2004) and Naik et al. (2010), we take the mixing ratio of ethanol in the lower latitude band of the MBL of the NH to be three times the mixing ratio of ethanol in the FT, namely $0.15 \mathrm{nmol} \mathrm{mol}^{-1}$.

The ethanol mixing ratio in the FT and the MBL of the $\mathrm{SH}$ is assumed to be half of that in the $\mathrm{NH}$ at all latitudes (Table 4), with an upper limit equal to that in the $\mathrm{NH}$ and a lower limit equal to one-fifth of that in the NH.

In urban areas, where a large proportion of ethanolblended fuels is utilised in motor vehicles, the atmospheric mixing ratios of ethanol are appreciably enhanced (Anderson, 2009; and references therein). For the 27 Brazilian sites reviewed by Anderson (2009), the mean mixing ratio of ethanol was $162-228 \mathrm{nmol} \mathrm{mol}^{-1}$. This mean mixing ratio is 160 times larger than the median ethanol mixing ratio in the CBL. At present, urban atmospheric ethanol measurements are few in number and almost non-existent in the $\mathrm{SH}$. 
Table 4. Ethanol removal rates from the various regions of the atmosphere by reaction with hydroxyl radicals, and the information used for the calculations.

\begin{tabular}{|c|c|c|c|c|c|c|c|c|}
\hline Division & CBL & MBL & FT & FT & CBL & MBL & FT & FT \\
\hline Cell Latitude & $90-30^{\circ}$ & $90-30^{\circ}$ & $90-30^{\circ}$ & $90-30^{\circ}$ & $30-0^{\circ}$ & $30-0^{\circ}$ & $30-0^{\circ}$ & $30-0^{\circ}$ \\
\hline Pressure range $(\mathrm{mb})$ & $1000-900$ & $1000-900$ & $900-500$ & $500-200$ & $1000-900$ & 1000-900 & $900-500$ & $500-200$ \\
\hline \multicolumn{9}{|l|}{ Northern Hemisphere } \\
\hline Temperature (K) & 282 & 282 & 261 & 230 & 288 & 288 & 276 & 242 \\
\hline$[\bullet \mathrm{OH}]\left(\right.$ radicals $\left.\mathrm{cm}^{-3}\right)$ & $1.1 \times 10^{6}$ & $5.8 \times 10^{5}$ & $5.8 \times 10^{5}$ & $5.2 \times 10^{5}$ & $1.1 \times 10^{6}$ & $1.3 \times 10^{6}$ & $1.3 \times 10^{6}$ & $1.1 \times 10^{6}$ \\
\hline$\left[\mathrm{C}_{2} \mathrm{H}_{5} \mathrm{OH}\right]\left(\mathrm{nmol} \mathrm{mol}^{-1}\right)$ & 1 & 0.15 & 0.05 & 0.05 & 1 & 0.15 & 0.05 & 0.05 \\
\hline Removal rate $\left(\mathrm{Tg} \mathrm{yr}^{-1}\right)$ & 11 & 0.90 & 2.3 & 1.5 & 6.3 & 2.9 & 5.3 & 3.3 \\
\hline \multicolumn{9}{|l|}{ Southern Hemisphere } \\
\hline Temperature (K) & 282 & 282 & 261 & 230 & 288 & 288 & 276 & 242 \\
\hline$[\bullet \mathrm{OH}]\left(\right.$ radicals $\left.\mathrm{cm}^{-3}\right)$ & $1.1 \times 10^{6}$ & $5.5 \times 10^{5}$ & $5.5 \times 10^{5}$ & $5.7 \times 10^{5}$ & $1.1 \times 10^{6}$ & $1.5 \times 10^{6}$ & $1.5 \times 10^{6}$ & $1.3 \times 10^{6}$ \\
\hline$\left[\mathrm{C}_{2} \mathrm{H}_{5} \mathrm{OH}\right]\left(\mathrm{nmol} \mathrm{mol}^{-1}\right)$ & 1 & 0.08 & 0.025 & 0.025 & 1 & 0.08 & 0.025 & 0.025 \\
\hline Removal rate $\left(\mathrm{Tg} \mathrm{yr}^{-1}\right)$ & 4.0 & 0.69 & 1.1 & 0.82 & 4.9 & 1.9 & 3.1 & 1.9 \\
\hline
\end{tabular}

\subsection{Ethanol removal from the atmosphere}

The major sink for ethanol in the atmosphere is its reaction with hydroxyl radicals (.OH) (Naik et al., 2010). The global loss rate of ethanol is estimated using the observed atmospheric mixing ratios of ethanol in the CBL, MBL and the FT, and the global distributions of $\cdot \mathrm{OH}$ concentrations with latitude and height determined by Prinn et al. (2001) using the methyl chloroform titration method. Since the $\cdot \mathrm{OH}$ concentrations vary significantly with latitude and altitude, we divide the troposphere into 3 vertical boxes and 2 latitudinal bands in each hemisphere (Table 4) to deal with any covariance between temperatures, $\cdot \mathrm{OH}$ concentrations and ethanol concentrations on these spatial scales. The lower boxes (1000-900 mb) are further sub-divided into the MBL and the CBL, which are assigned different concentrations of ethanol. The ethanol loss rate in each box is determined using the temperature-dependent reaction rate constant expression derived by Jiménez et al. (2003). Separate calculations are made for each box, and the loss rates are then combined to give a single representative loss rate for the FT, MBL or CBL in the global troposphere. The ranges of the ethanol losses are determined from the estimated uncertainty in the ethanol concentrations in each division of the troposphere and the uncertainties provided by Prinn et al. (2001) for $\cdot \mathrm{OH}$ concentrations and Jiménez et al. (2003) for reaction rate constants.

The hydroxyl radical is the most reactive species with dissolved VOCs in cloud water (Herrmann et al., 1999). Ethanol has an aqueous-phase reaction rate constant with $\cdot \mathrm{OH}$ of $(1.3 \pm 0.7) \times 10^{9} 1 \mathrm{~mol}^{-1} \mathrm{~s}^{-1}$ (Ervens et al., 2003) at $276 \mathrm{~K}$, the average temperature of clouds (Lelieveld and Crutzen, 1991). Using data from Lelieveld et al. (1989), the mass of cloud water is estimated to be $38 \mathrm{Pg}$ in the $\mathrm{NH}$ and $42 \mathrm{Pg}$ in the $\mathrm{SH}$. The $\cdot \mathrm{OH}$ concentration in the aqueous-phase of clouds is taken as $(7 \pm 5) \times 10^{-14} \mathrm{moll}^{-1}$ (Herrmann et al., 2000; Leriche et al., 2000). The global loss rate due to $\cdot \mathrm{OH}$ oxidation of ethanol in the aqueous phase of the atmosphere is calculated as 0.4 (range, $0.2-0.8) \mathrm{Tg} \mathrm{yr}^{-1}$, with approximately equal contributions from each hemisphere.

In the gaseous and liquid phases of the troposphere, an ethanol loss rate with respect to $\cdot \mathrm{OH}$ of 53 (range, 3472) $\mathrm{Tg} \mathrm{yr}^{-1}$ is estimated. The higher loss rate of ethanol in the CBL, in comparison to the FT and MBL, is the consequence of the higher ethanol mixing ratio in the CBL.

As well as this loss of ethanol by reaction with $\cdot \mathrm{OH}$, ethanol is removed from the atmosphere by dry deposition and wet deposition (Naik et al., 2010). It is assumed that any ethanol that is transferred to the terrestrial surface through deposition processes will be lost through soil water absorption and subsequent microbial action. Ethanol that is transferred to the ocean through deposition represents a loss to the atmosphere, but a source to the ocean. Since the ocean is considered as a net source of ethanol to the atmosphere (Beale et al., 2010), only deposition over land is included as an atmospheric loss.

Ethanol removal rates for dry deposition and wet deposition are calculated using approaches similar to those used in Galbally and Kirstine (2002). Since representative values for the dry deposition velocity of ethanol are not available in the literature, a deposition velocity of $0.16 \mathrm{~cm} \mathrm{~s}^{-1}$ is used, equal to that derived for methanol by von Kuhlmann et al. (2003). For an average height of the CBL of $1000 \mathrm{~m}$, the global ethanol loss by dry deposition is 14 (range, 722) $\mathrm{Tg} \mathrm{yr}^{-1}$ (Table 5). Loss of ethanol by wet deposition occurs in the CBL through rainfall, taken here to be 
Table 5. Global atmospheric sinks of ethanol in $\mathrm{Tg}$ (ethanol) $\mathrm{yr}^{-1}$. Numbers in parentheses are the estimated ranges of the sinks.

\begin{tabular}{lcr}
\hline Sinks $\left(\mathrm{Tg} \mathrm{yr}^{-1}\right)$ & $\begin{array}{c}\text { Naik et al. (2010) } \\
\text { BASE }\end{array}$ & This study \\
\hline Atmospheric oxidation & 9.6 & $53(34-72)$ \\
Dry deposition & 3.7 & $14(7-22)$ \\
Wet deposition & 1.4 & $3(2-4)$ \\
Total Sinks & 14.7 & $70(50-90)$ \\
\hline
\end{tabular}

$800 \mathrm{~mm} \mathrm{yr}^{-1}$ (Sanderson, 1990). A Henry's law constant of $483 \mathrm{moll}^{-1} \mathrm{~atm}^{-1}$ is used, appropriate to the average temperature of the CBL. Global wet deposition of ethanol is calculated to be 3 (range, 2-4) $\mathrm{Tg} \mathrm{yr}^{-1}$ (Table 5).

Calculations based on the observed atmospheric concentrations of ethanol indicate a global removal rate of 53 (range, 34-72) $\mathrm{Tg} \mathrm{yr}^{-1}$ by hydroxyl radicals, and smaller removal rates of 14 (range, 7-22) $\mathrm{Tg} \mathrm{yr}^{-1}$ and 3 (range, 2-4) $\mathrm{Tg} \mathrm{yr}^{-1}$ due to dry deposition and wet deposition, respectively, giving a global loss rate of 70 (range, 50-90) $\mathrm{Tg} \mathrm{yr}^{-1}$ (Table 5). Although the overlap of the ranges of ethanol emissions and losses is not large, this atmospheric ethanol loss rate estimate is not significantly larger than the ethanol source from plants estimated earlier.

The ratio of the three removal processes $(\cdot \mathrm{OH}$ oxidation, dry deposition and wet deposition) calculated here is $75: 21: 4 \%$. In comparison, Millet et al. (2010) indicated that $77 \%$ of the ethanol in the atmosphere is removed by $\cdot \mathrm{OH}$ oxidation and the remaining $23 \%$ is removed by dry and wet deposition, but they do not explicitly provide removal rates. Naik et al. (2010) calculated a ratio of 65:25:10\% for removal by $\mathrm{OH}$ oxidation, dry deposition and wet deposition, respectively.

In this study, the global ethanol sink is calculated from measured concentrations of ethanol and hydroxyl radicals (along with contributions from wet and dry deposition). This is a slightly different approach to Naik et al. (2010) who increased sources within their model by $29.3 \mathrm{Tg} \mathrm{yr}^{-1}$ to get a better fit of modelled and observed concentrations. Within the Naik et al. (2010) study, it does not appear that the sources were completely adjusted so that modelled atmospheric concentrations fitted the measured global average concentration.

In this study, no attempt is made to develop a global atmospheric model for ethanol that balances the ethanol sources and sinks. Instead, the sources and sinks are estimated independently using the atmospheric measurements available in the literature. From our calculations, the global ethanol sink of 70 (range, 50-90) $\mathrm{Tg} \mathrm{yr}^{-1}$ has only a small extent of overlap with the global ethanol source of 42 (range, 2556) $\mathrm{Tg}_{\mathrm{yr}}{ }^{-1}$. The reason for this is not clear, but may be a consequence of the lack of ethanol flux measurements from wetlands, rice paddies, non-flooded tropical forests, cultivated land, desert and semi-arid shrubland. Equally, it may be due to the scarcity of representative ethanol flux and atmospheric concentration data.

The question that occurs is whether or not the ethanol sources and sinks in the atmosphere are in balance. Given the short lifetime of ethanol in the atmosphere (approximately 3 days), and the fact that the ethanol sink is first order dependent on atmospheric ethanol concentrations, we would expect over a period of a month or so that the sources and sinks would be in balance. However, due to the heterogeneity of the sources in space and time and the short atmospheric lifetime, it is expected that the atmospheric concentrations of ethanol will have more variance in space and time than other longer lived atmospheric species, with the variability of ethanol being more comparable with that of water vapour or radon (Junge, 1974).

\section{Conclusions}

The atmospheric ethanol cycle is examined from the point of view of what information can be obtained solely from the available observations. Calculations, based on the available measurements of plant/atmosphere emissions of ethanol, suggest an emission rate of ethanol from living plants of 26 (range, 10-38) $\mathrm{Tg} \mathrm{yr}^{-1}$. This gives a total global ethanol source of 42 (range, 25-56) $\mathrm{Tg} \mathrm{yr}^{-1}$. The large uncertainties associated with these estimates are a consequence of the existence of only seven studies of ethanol emission fluxes from plants, some of short duration. The most serious neglect in this estimate is the omission of potential ethanol emissions from wetlands (excluding flooded forests) and rice paddies where there are no measurements.

Within the troposphere of the Northern Hemisphere, ethanol has an observed mixing ratio of about $1 \mathrm{nmol} \mathrm{mol}^{-1}$ in the continental boundary layer, $0.15 \mathrm{nmol} \mathrm{mol}^{-1}$ in the marine boundary layer, and $0.05 \mathrm{nmol} \mathrm{mol}^{-1}$ in the free troposphere. Ethanol mixing ratios in the Southern Hemisphere are less well defined.

The global removal rate of ethanol from the troposphere is estimated from observed atmospheric ethanol concentrations as 53 (range, 34-72) $\mathrm{Tg} \mathrm{yr}^{-1}$ due to reaction with hydroxyl radicals, and 14 (range, $7-22) \mathrm{Tg} \mathrm{yr}^{-1}$ and 3 (range, 2-4) $\mathrm{Tg} \mathrm{yr}^{-1}$ due to dry deposition and wet deposition, respectively. Given the uncertainties in these estimates, and the short lifetime of ethanol in the atmosphere ( $\sim 3$ days), the total ethanol sinks cannot be considered significantly different from the total ethanol sources.

These two independent estimates of the annual cycling of ethanol through the atmosphere are significantly larger than those in recent literature. Naik et al. (2010) recently presented the first global atmospheric budget for ethanol based on a model study; however, they indicated that "current levels of ethanol measured in remote regions are an order of 
magnitude larger than those in the model, suggesting a major gap in understanding". We suggest that this discrepancy results from an under-estimation of the amount of ethanol produced from living plants.

\section{Supplementary material related to this article is available online at: http://www.atmos-chem-phys.net/12/545/2012/ acp-12-545-2012-supplement.pdf.}

Edited by: P. Monks

\section{References}

Anderson, J. G.: Ethanol fuel use in Brazil: air quality impacts, Energy Environ. Sci., 2, 1015-1037, 2009.

Beale, R., Liss, P. S., and Nightingale, P. D.: First ocean measurements of ethanol and propanol, Geophys. Res. Lett., 37, L24607, doi:10.1029/2010GL045534, 2010.

Boudries, H., Bottenheim, J. W., Guimbaud, C., Grannas, A. M., Shepson, P. B., Houdier, S., Perrier, S., and Dominé, F.: Distribution and trends of oxygenated hydrocarbons in the high Arctic derived from measurements in the atmosphere boundary layer and interstitial snow air during ALERT2000 field campaign, Atmos. Environ., 36, 2573-2583, 2002.

Chawanakul, S., Chaiprasert, P., Towprayoon, S., and Tanticharoen, M.: Contributions of available substrates and activities of trophic microbial community to methanogenesis in vegetative and reproductive rice rhizospheric soil, J. Environ. Biol., 30, 119-127, 2009.

Chung, M. Y., Beene, M., Ashkan, S., Krauter, C., and Hasson, A. S.: Evaluation of non-enteric sources of non-methane volatile organic compound (NMVOC) emissions from dairies, Atmos. Environ., 44, 786-794, 2010.

Cullen, A. C. and Frey, H. C.: Probabilistic Techniques in Exposure Assessment, Plenum Press, NY, 1999.

de Gouw, G. A., Middlebrook, A. M., Warneke, C., Goldan, P. D., Kuster, W. C., Roberts, J. M., Fehsenfeld, F. C., Worsnop, D. R., Canagaratna, M. R., Pszenny, A. A. P., Keene, W. C., Marchewka, M., Bertman, S. B., and Bates, T. S.: Budget of organic carbon in a polluted atmosphere: results from the New England Air Quality Study in 2002, J. Geophys. Res., 110, D16305, doi:10.1029/2004JD005623, 2005.

Ervens, B., Gligorovski, S., and Herrmann, H.: Temperaturedependent rate constants for hydroxyl radical reactions with organic compounds in aqueous solution, Phys. Chem. Chem. Phys., 5, 1811-1824, 2003.

Esser, G.: Implications of climate change for production and decomposition in grasslands and coniferous forests, Ecol. Appl., 2, 47-54, 1992.

Fehsenfeld, F., Calvert, J., Fall, R., Goldan, P., Guenther, A. B., Hewitt, C.N., Lamb, B., Liu, S., Trainer, M., Westberg, H., and Zimmerman, P.: Emissions of volatile organic compounds from vegetation and the implications for atmospheric chemistry, Global Biogeochem. Cy., 6, 389-430, 1992.

Filipy, J., Rumburg, B., Mount, G., Westberg, H., and Lamb, B.: Identification and quantification of volatile organic compounds from a dairy, Atmos. Environ., 40, 1480-1494, 2006.

Fukui, Y. and Doskey, P. V.: Air-surface exchange of nonmethane organic compounds at a grassland site: seasonal variations and stressed emissions, J. Geophys. Res., 103, 13153-13168, 1998.

Galbally, I. E. and Kirstine, W.: The production of methanol by flowering plants and the global cycle of methanol, J. Atmos. Chem., 43, 195-229, 2002.

Gilman, J. B., Kuster, W. C., Goldan, P. D., Herndon, S. C., Zahniser, M. S., Tucker, S. C., Brewer, W. A., Lerner, B. M., Williams, E. J., Harley, R. A., Fehsenfeld, F. C., Warneke, C., and de Gouw, J. A.: Measurements of volatile organic compounds during the 2006 TexAQS/GoMACCS campaign: industrial influences, regional characteristics, and diurnal dependencies of the $\mathrm{OH}$ reactivity, J. Geophys. Res., 114, D00F06, doi:10.1029/2008JD011525, 2009.

Goldan, P. D., Kuster, W. C., and Fehsenfeld, F. C.: Hydrocarbon measurements in the southeastern United States: the rural oxidants in the southern environment (ROSE) program 1990, J. Geophys. Res., 100, 25945-25963, 1995a.

Goldan, P. D., Trainer, M., Kuster, W. C., Parrish, D. D., Carpenter, J., Roberts, J. M., Yee, J. E., and Fehsenfeld, F. C.: Measurements of hydrocarbons, oxygenated hydrocarbons, carbon monoxide, and nitrogen oxides in an urban basin in Colorado: implications for emission inventories, J. Geophys. Res., 100, 22771-22783, 1995 b.

Grabmer, W., Kreuzwieser, J., Wisthaler, A., Cojocariu, C., Graus, M., Rennenberg, H., Steigner, D., Steinbrecher, R., and Hansel, A.: VOC emissions from Norway spruce (Picea abies L. [Karst]) twigs in the field - results of a dynamic enclosure study, Atmos. Environ., 40, S128-S137, 2006.

Guenther, A., Zimmerman, P., and Wildermuth, K.: Natural volatile organic compound emission rate estimates for U.S. woodland landscapes, Atmos. Environ., 28, 1197-1210, 1994.

Helmig, D., Klinger, L. F., Guenther, A., Vierling, L., Geron, C., and Zimmerman, P.: Biogenic volatile organic compound emissions (BVOCs) I. Identifications from three continental sites in the U.S., Chemosphere, 38, 2163-2187, 1999.

Herrmann, H., Ervens, B., Nowacki, P., Wolke, R., and Zellner, R.: A chemical aqueous phase radical mechanism for tropospheric chemistry, Chemosphere, 38, 1223-1232, 1999.

Herrmann, H., Ervens, B., Jacobi, H.-W., Wolke, R., Nowacki, P., and Zellner, R.: CAPRAM2.3: A chemical aqueous phase radical mechanism for tropospheric chemistry, J. Atmos. Chem., 36, 231-284, 2000.

Holzinger, R., Sandoval-Soto, L., Rottenberger, S., Crutzen, P. J., and Kesselmeier, J.: Emissions of volatile organic compounds from Quercus ilex L. measured by Proton Transfer Reaction Mass Spectrometry under different environmental conditions, J. Geophys. Res., 105, 20573-20579, 2000.

Jiménez, E., Gilles, M. K., and Ravishankara, A. R.: Kinetics of the reactions of the hydroxyl radical with $\mathrm{CH}_{3} \mathrm{OH}$ and $\mathrm{C}_{2} \mathrm{H}_{5} \mathrm{OH}$ between 235 and 360 K, J. Photochem. Photobiol. A, 157, 237245, 2003.

Jonsson, A., Persson, K. A., and Grigoriadis, V.: Measurements of some low molecular-weight oxygenated, aromatic, and chlorinated hydrocarbons in ambient air and in vehicle emissions, Environ. Internat., 11, 383-392, 1985.

Junge, C. E.: Residence time and variability of tropospheric trace gases, Tellus, 26, 477-488, 1974. 
Kimmerer, T. W. and MacDonald, R. C.: Acetaldehyde and ethanol biosynthesis in leaves of plants, Plant Physiol., 84, 1204-1209, 1987.

Kirstine, W. and Galbally, I. E.: Ethanol in the environment - a critical review of its roles as a natural product, a biofuel and a potential environmental pollutant, Crit. Rev. Environ. Sci. Technol., accepted, 2011.

Kirstine, W., Galbally, I. E., Ye, Y., and Hooper, M. A.: Emissions of volatile organic compounds (primarily oxygenated species) from pasture, J. Geophys. Res., 103, 10605-10620, 1998.

Kreuzwieser, J., Papadopoulou, E., and Rennenberg, H.: Interaction of flooding with carbon metabolism of forest trees, Plant Biol., 6, 299-306, 2004.

Legreid, G., Lööv, J. B., Staehelin, J., Hueglin, C., Hill, M., Buchmann, B., Prevot, A. S. H., and Reimann, S.: Oxygenated volatile organic compounds (OVOCs) at an urban background site in Zürich (Europe): seasonal variation and source allocation, Atmos. Environ., 41, 8409-8423, 2007.

Legreid, G., Folini, D., Staehelin, J., Lööv, J. B., Steinbacher, M., and Reimann, S.: Measurements of organic trace gases including oxygenated volatile organic compounds at the high altitude site Jungfraujoch (Switzerland): seasonal variation and source allocations, J. Geophys. Res., 113, D05307, doi:10.1029/2007JD008653, 2008.

Leibrock, E. and Slemr, J.: Method for measurement of volatile oxygenated hydrocarbons in ambient air, Atmos. Environ., 31, 3329-3339, 1997.

Lelieveld, J. and Crutzen, P. J.: The role of clouds in tropospheric photochemistry, J. Atmos. Chem., 12, 229-267, 1991.

Lelieveld, J., Crutzen, P. J., and Rodhe, H.: Zonal average cloud characteristics for global atmospheric chemistry modelling, GLOMAC Report CM-76, UDC 551.510.4, International Meteorological Institute of Stockholm, 1989.

Leriche, M., Voisin, D., Chaumerliac, N., Monod, A., and Aumont, B.: A model for tropospheric multiphase chemistry: application to one cloudy event during the CIME experiment, Atmos. Environ., 34, 5015-5036, 2000.

MacDonald, R. C. and Kimmerer, T. W.: Metabolism of transpired ethanol by eastern cottonwood (Populus deltoides Bartr.), Plant Physiol., 102, 173-179, 1993.

Metje, M. and Frenzel, P.: Effect of temperature on anaerobic ethanol oxidation and methanogenesis in acidic peat from a northern wetland, Appl. Environ. Microbiol., 71, 8191-8200, 2005.

Millet, D. B., Goldstein, A. H., Allan, J. D., Bates, T. S., Boudries, H., Bower, K. N., Coe, H., Ma, Y., McKay, M., Quinn, P. K., Sullivan, A., Weber, R. J., and Worsnop, D. R.: Volatile organic compound measurements at Trinidad Head, California, during ITCT 2K2: analysis of sources, atmospheric composition, and aerosol residence times, J. Geophys. Res., 109, D23S16, doi:10.1029/2003JD004026, 2004.

Millet, D. B., Donahue, N. M., Pandis, S. N., Polidori, A., Stanier, C. O., Turpin, B. J., and Goldstein, A. H.: Atmospheric volatile organic compound measurements during Pittsburgh Air Quality Study: results, interpretation, and quantification of primary and secondary contributions, J. Geophys. Res., 110, D07S07, doi:10.1029/2004JD004601, 2005.

Millet, D. B., Goldstein, A. H., Holzinger, R., Williams, B. J., Allan, J. D., Jimenez, J. L., Worsnop, D. R., Roberts, J. M., White,
A. B., Hudman, R. C., Bertschi, I. T., and Stohl, A.: Chemical characteristics of North American surface layer outflow: insights from Chebogue Point, Nova Scotia, J. Geophys. Res., 111, D23S53, doi:10.1029/2006JD007287, 2006.

Millet, D. B., Guenther, A., Siegel, D. A., Nelson, N. B., Singh, H. B., de Gouw, J. A., Warneke, C., Williams, J., Eerdekens, G., Sinha, V., Karl, T., Flocke, F., Apel, E., Riemer, D. D., Palmer, P. I., and Barkley, M.: Global atmospheric budget of acetaldehyde: 3-D model analysis and constraints from in-situ and satellite observations, Atmos. Chem. Phys., 10, 3405-3425, doi:10.5194/acp-10-3405-2010, 2010.

Murphy, J. G., Day, D. A., Cleary, P. A., Wooldridge, P. J., Millet, D. B., Goldstein, A. H., and Cohen, R. C.: The weekend effect within and downwind of Sacramento - Part 1: Observations of ozone, nitrogen oxides, and VOC reactivity, Atmos. Chem. Phys., 7, 5327-5339, doi:10.5194/acp-7-5327-2007, 2007.

Naik, V., Fiore, A. M., Horowitz, L. W., Singh, H. B., Wiedinmyer, C., Guenther, A., de Gouw, J. A., Millet, D. B., Goldan, P. D., Kuster, W. C., and Goldstein, A.: Observational constraints on the global atmospheric budget of ethanol, Atmos. Chem. Phys., 10, 5361-5370, doi:10.5194/acp-10-5361-2010, 2010.

Nguyen, H. T., Takenaka, N., Bandow, H., Maeda, Y., de Oliva, S. T., Botelho, M. M., and Tavares, T. M.: Atmospheric alcohols and aldehydes concentrations measured in Osaka, Japan and in São Paulo, Brazil, Atmos. Environ., 35, 3075-3083, 2001.

Ngwabie, N. M., Schade, G. W., Custer, T. G., Linke, S., and Hinz, T.: Abundances and flux estimates of volatile organic compounds from a dairy cowshed in Germany, J. Environ. Qual., 37, 565573, 2008.

Niedojadlo, A., Becker, K. H., Kurtenbach, R., and Wiesen, P.: The contribution of traffic and solvent use to the total NMVOC emission in a German city derived from measurement and CMB modelling, Atmos. Environ., 41, 7108-7126, 2007.

Potere, D., Schneider, A., Angel, S., and Civco, D. L.: Mapping urban areas on a global scale: which of the eight maps now available is more accurate?, Int. J. Remote Sens., 30, 6531-6558, 2009.

Potter, C. S.: Terrestrial biomass and effects of deforestation on the global carbon cycle, Bioscience, 49, 769-778, 1999.

Prinn, R. G., Huang, J., Weiss, R. F., Cunnold, D. M., Fraser, P. J., Simmonds, P. G., McCulloch, A., Harth, C., Salemeh, P., O'Doherty, S., Wang, R. H., Porter, L., and Miller, B. R.: Evidence for substantial variations of atmospheric hydroxyl radicals in the past two decades, Science, 292, 1882-1888, 2001.

Riemer, D., Pos, W., Milne, P., Farmer, C., Zika, R., Apel, E., Olszyna, K., Kleindienst, T., Lonneman, W., Bertman, S., Shepson, P., and Starn, T.: Observations of nonmethane hydrocarbons and oxygenated organic compounds at a rural site in the southeastern United States, J. Geophys. Res., 103, 28111-28128, 1998.

Rottenberger, S., Kleiss, B., Kuhn, U., Wolf, A., Piedade, M. T. F., Junk, W., and Kesselmeier, J.: The effect of flooding on the exchange of the volatile $\mathrm{C}_{2}$-compounds ethanol, acetaldehyde and acetic acid between leaves of Amazonian floodplain tree species and the atmosphere, Biogeosciences, 5, 1085-1100, doi:10.5194/bg-5-1085-2008, 2008.

Sanderson, M.: UNESCO Sourcebook in Climatology, UNESCO, France, 1990.

Schade, G. W. and Goldstein, A. H.: Fluxes of oxygenated volatile organic compounds from a ponderosa pine plantation, 
J. Geophys. Res., 106, 3111-3123, 2001.

Shaw, S. L., Mitloehner, F. M., Jackson, W., Depeters, E. J., Fadel, J. G., Robinson, P. H., Holzinger, R., and Goldstein, A. H.: Volatile organic compound emissions from dairy cows and their waste as measured by proton-transfer-reaction mass spectrometry, Environ. Sci. Technol., 41, 1310-1316, 2007.

Singh, H., Chen, Y., Tabazadeh, A. Fukui, Y., Bey, I., Yantosca, R., Jacob, D., Arnold, F., Wohlfrom, K., Atlas, E., Flocke, F., Blake, D, Blake, N., Heikes, B., Snow, J., Talbot, R., Gregory, G., Sachse, G., Vay, S., and Kondo, Y.: Distribution and fate of selected oxygenated organic species in the troposphere and lower stratosphere over the Atlantic, J. Geophys. Res., 105, 3795-3805, 2000.

Singh, H., Chen, Y., Staudt, A., Jacob, D., Blake, D., Heikes, B., and Snow, J.: Evidence for the Pacific troposphere for large global sources of oxygenated organic compounds, Nature, 410, 1078-1081, 2001.

Singh, H., Salas, L. J., Chatfield, R. B., Czech, E., Fried, A., Walega, J., Evans, M. J., Field, B. D., Jacob, D. J., Blake, D., Heikes, B., Talbot, R., Sachse, G., Crawford, J. H., Avery, M. A., Sandholm, S., and Fuelberg, H.: Analysis of the atmospheric distribution, sources, and sinks of oxygenated volatile organic chemicals based on measurements over the Pacific during TRACE-P, J. Geophys. Res., 109, D15S07, doi:10.1029/2003JD003883, 2004.

Singh, H., Brune, W. H., Crawford, J. H., Jacob, D. J., and Russell, P. B.: Overview of the summer 2004 Intercontinental Chemical Transport Experiment-North America (INTEX-A), J. Geophys. Res., 111, D24S01, doi:10.1029/2006JD007905, 2006.
Singh, H. B., Kanakidou, M., Crutzen, P. J., and Jacob, D. J.: High concentrations and photochemical fate of oxygenated hydrocarbons in the global troposphere, Nature, 378, 50-54, 1995.

Singh, H. B., Brune, W. H., Crawford, J. H., Flocke, F., and Jacob, D. J.: Chemistry and transport of pollution over the Gulf of Mexico and the Pacific: spring 2006 INTEX-B campaign overview and first results, Atmos. Chem. Phys., 9, 2301-2318, doi:10.5194/acp-9-2301-2009, 2009.

Snider, J. R. and Dawson, G. A.: Tropospheric light alcohols, carbonyls, and acetonitrile: concentrations in the southwestern United States and Henry's law data, J. Geophys. Res., 90, $3797-$ 3805, 1985.

Sun, H., Trabue, S. L., Scoggin, K., Jackson, W. A., Pan, Y., Zhao, Y., Malkina, I. L., Koziel, J. A., and Mitloehner, F. M.: Alcohol, volatile fatty acid, phenol, and methane emissions from dairy cows and fresh manure, J. Environ. Qual., 37, 615-622, 2008.

von Kuhlmann, R., Lawrence, M. G., Crutzen, P. J., and Rasch, P. J.: A model for the studies of atmospheric ozone and non-methane hydrocarbons: model description and ozone results, J. Geophys. Res., 108, 4294, doi:10.1029/2002JD002893, 2003.

Warneke, C., Kato, S., de Gouw, J. A., Goldan, P. D., Kuster, W. C., Shao, K., Lovejoy, E. R., Fall, R., and Fehsenfeld, F. C.: Online volatile organic compound measurements using a newly developed proton-transfer ion-trap mass spectrometry instrument during New England Air Quality Study - Intercontinental Transport and Chemical Transformation 2004: Performance, intercomparison, and compound identification, Environ. Sci. Technol., 39, 5390-5397, 2005. 